\title{
Peningkatan Keterampilan Menulis Sajak dengan Menggunakan Media Gambar pada Siswa
}

\author{
Improving Poetry Writing Skills by using Picture Media for Students
}

\author{
Yayat Cahyati \\ SMP Negeri 2 Jatinangor, Sumedang, Jawa Barat, Indonesia \\ yayat.cahyati@gmail.com
}

Naskah diterima tanggal 26/02/2019, direvisi akhir tanggal 22/04/2019, disetujui tanggal 30/04/2019

\begin{abstract}
Abstrak
Penelitian ini bertujuan untuk meningkatkan pembelajaran menulis sajak dengan menggunakan media gambar. Adapun jenis penelitian yaitu penelitian tindakan kelas. Subjek penelitian adalah siswa kelas kelas VII-A SMP Negeri 2 Jatinangor Kabupaten Sumedang. Pendekatan penelitian yang digunakan adalah penelitian tindakan kelas yang dilakukan dalam dua siklus, setiap siklus terdiri atas perencanaan, pelaksanaan, observasi dan refleksi. Metode pengumpulan data yang digunakan adalah observasi, tes, angket dan dokumentasi. Adapun sifat dari penelitian ini adalah deskriptif kualitatif, karena pendekatan ini hanya mendeskripsikan data kemudian dianalisis. Proses pembelajaran menulis sajak dengan menggunakan media gambar ternyata lebih menarik perhatian siswa, siswa dapat lebih banyak menemukan inspirasi dan ide dalam menulis sajak. Gambar atau foto yang ditempelkan di papan tulis oleh guru dapat memberikan gambaran tentang segala sesuatu seperti suasana atau peristiwa tertentu yang dapat membawa imajinasi siswa ke tempat tersebut, dari hasil penelitian menunjukkan bahwa proses pembelajaran menulis sajak mengalami peningkatan setelahmenggunakan media gambar, berdasarkan hasil observasi awal terlihat bahwa keterampilan menulis sajak siswa masih rendah. Terdapat beberapa siswa masih mendapatkan nilai 55,13 dalam kegiatan menulis sajak Peningkatan hasil belajar siswa dalam menulis sajak pada siklus I nilai rata-rata mencapai 67,01 dengan kategori cukup. Rata-rata ini menunjukkan terjadinya peningkatan keterampilan menulis sajak dengan menggunakan media gambar dibandingkan dengan rata-rata pada kondisi awal, dan dari hasil siklus II diperoleh nilai rata-rata siswa sebesar 81,94 dengan kategori sangat baik.
\end{abstract}

Kata kunci: keterampilan menulis sajak, media gambar.

\begin{abstract}
This study aims to improve learning to write poems using media images. The type of research is classroom action research. The research subjects were class students of class VII-A Jatinangor State Junior High School 2 Sumedang District. The research approach used is classroom action research conducted in two cycles, each cycle consisting of planning, implementation, observation and reflection. Data collection methods used are observation, tests, questionnaires and documentation. The nature of this study is descriptive qualitative, because this approach only describes the data then analyzed. The process of learning to write poems using picture media turned out to be more interesting to students, students could find more inspiration and ideas in writing poems. The picture or photo affixed on the board by the teacher can give an idea of everything such as a certain atmosphere or event that can bring the student's imagination to the place, from the results of the study that the learning process of writing poetry has increased after using media images, based on the results of initial observations it appears that students' poetry writing skills are still low. There are some students still get a value of 55.13 in writing poetry activities Improved student learning outcomes in writing poems in the first cycle the
\end{abstract}


average value reaches 67.01 with sufficient categories. This average indicates an increase in poetry writing skills by using image media compared to the average in the initial conditions, and from the results of the second cycle obtained an average value of students of 81.94 with a very good category

Keywords: poetry writing skills, picture media.

\section{PENDAHULUAN}

Pendidikan muatan lokal bahasa Sunda yang terintegrasi pada mata pelajaran seni budaya berdasarkan pada kurikulum 2013, seyogyanya tidak meniadakan esensi dari tujuan pembelajaran muatan lokal bahasa Sunda itu sendiri, yaitu memberikan kompetensi kepada siswa tentang berbagai keterampilan berbahasa sunda yang meliputi kompetensi cakap berbahasa, berolah sastra, dan berbudaya sunda. Kecakapan yang terintegrasi tersebut dimulai pada pembelajaran di kelas VII. Selain memberikan bekal penguasaan keterampilan berbahasa, pengintegrasian bahasa Sunda di jenjang sekolah menengah pertama, salah satunya adalah melalui pembelajaran keterampilan menulis, juga membekali siswa mengenai kesantunan berbahasa sesuai konteks budaya Sunda.

Prinsip yang mendasari guru dalam mengajarkan bahasa sunda sebagai sebuah keterampilan berbahasa antara lain pengintegrasian antara bentuk dan makna, penekanan pada kemampuan berbahasa praktis dan interaksi yang produktif antara guru dengan siswa. Prinsip pertama menyarankan agar pengetahuan dan keterampilan berbahasa yang diperoleh dapat berguna dalam komunikasi sehari-hari (meaningful). Dengan kata lain agar dihindari penyajian materi yang tidak bermanfaat dalam komunikasi sehari-hari, misalnya, pengetahuan tata bahasa sunda yang sangat linguistis. Prinsip kedua menekankan bahwa melalui pembelajaran bahasa sunda, siswa diharapkan mampu menangkap ide yang diungkapkan baik lisan maupun tertulis, penilaian hanya sebagai sarana pembelajaran bahasa, bukan sebagai tujuan. Sedangkan prinsip ketiga mengharapkan agar di kelas bahasa tercipta masyarakat pemakai bahasa sunda yang produktif. Tidak ada peran guru yang dominan, guru diharapkan sebagai 'pemicu' kegiatan berbahasa lisan dan tulis, disini peran guru sebagai orang yang paling tahu atau pemberi informasi pengetahuan bahasa sunda agar dihindari.

Pada pelajaran bahasa sunda untuk SMP Kelas VII pada Kurikulum 2013 disusun dengan berbasis teks, baik lisan maupun tulis dengan menempatkan bahasa daerah (sunda) sebagai wahana pengetahuan. Di dalamnya dijelaskan berbagai cara penyajian pengetahuan dengan berbagai macam jenis teks. Pemahaman terhadap jenis, kaidah dan konteks suatu teks ditekankan sehingga memudahkan siswa menangkap makna yang terkandung dalam suatu teks maupun menyajikan gagasan dalam bentuk teks yang sesuai sehingga memudahkan orang lain memahami gagasan yang ingin disampaikan.

Sebagai bagian dari Kurikulum 2013 yang menekankan pentingnya keseimbangan kompetensi sikap, pengetahuan dan keterampilan, kemampuan berbahasa yang dituntut tersebut dibentuk melalui pembelajaran berkelanjutan dimulai dengan meningkatkan kompetensi pengetahuan tentang jenis, kaidah dan konteks suatu teks, dilanjutkan dengan kompetensi keterampilan menyajikan suatu teks tulis dan lisan baik terencana maupun spontan, dan bermuara pada pembentukan sikap kesantunan 
berbahasa dan penghargaan terhadap bahasa daerah (sunda) sebagai bagian dari warisan budaya bangsa.

Terkait evaluasi hasil pembelajaran, kurikulum 2013 menghendaki evaluasi secara holistik mencakup aspek sikap (baik sikap personal, sosial, maupun spiritual/ religius) pengetahuan, dan keterampilan. Penilaian dilakukan bukan hanya dengan metoda tes (ulangan/ujian tertulis) tetapi juga menggunakan metode non tes (portofolio) dimana penilaian dilakukan terhadap proses yang mencakup pada ranah sikap unjuk kerja/performance, dan hasil karya dengan menggunakan autentic assesment. Melalui proses pembelajaran dan proses penilaian seperti tersebut di atas, dimana penilaian sikap, pengetahuan, dan keterampilan berbahasa dilakukan secara terintegrasi, diharapkan pembelajaran bahasa sunda dapat menghasilkan siswa yang produktif, kreatif, inovatif, dan afektif sesuai dengan tema pengembangan kurikulum 2013.

Budaya sunda yang sarat dengan nilai-nilai pendidikan budaya dan karakter yang terkandung dalam filosofi kehidupan masyarakat sunda. Filsafat sunda merupakan sarana untuk mempertinggi tingkat rohani agar dapat meraih nilai-nilai keutamaan. Sejalan dengan hal tersebut filsafat sunda juga dapat berbentuk ungkapan-ungkapan atau renungan-renungan, berbentuk kiasan atau lambang.ungkapan-ungkapan sunda yang terkait dengan nilai-nilai budaya dan karakter "urang sunda", agar selalu menjaga tutur kata dan menjaga perilaku dimanapun berada.

Pembelajaran bahasa Sunda sebagai bagian dari proses berkomunikasi sangatlah penting. Oleh karena itu, pembelajaran bahasa Sunda mengupayakan peningkatan kemampuan berkomunikasi secara lisan dan tertulis. Pembelajaran bahasa Sunda yang terdiri atas empat keterampilan berbahasa (menyimak, membaca, berbicara, dan menulis) menjadi sebuah mata pelajaran yang aktif produktif. artinya dalam pembelajaran bahasa siswa tidak hanya berkutat pada teori berbahasa, tetapi ditekankan pada sikap dan pemakaian bahasa yang kontekstual.

Salah satu materi ajar yang diberikan pada siswa kelas VII adalah mengenai keterampilan menulis sajak sunda, Keterampilan menulis sajak sunda wajib dikuasai oleh siswa, tujuannya adalah agar siswa dapat mengkespresikan pikiran, perasaaan, pengalaman, dan imajinasinya melalui kegiatan menulis sajak sunda secara kreatif. Proses pengimajinasian atau pengembangan pengalaman lahir dan batin merupakan awal dari proses kreatif. Proses kreatif tersebut kemudian dilanjutkan dengan pengekspresian imajinasi ke dalam rangkaian kata-kata yang disebut dengan istilah sajak sunda.

Keterampilan menulis sajak lebih sulit dikuasai. Hal ini karena diperlukan kemampuan untuk menguasai berbagai unsur kebahasaan dan unsur di luar bahasa itu sendiri yang akan menjadi isi tulisan. Baik unsur bahasa maupun unsur ini harus saling berkaitan sehingga tulisan menjadi runtut dan terpadu.keterampilan menulis dapat dipandang sebagai salah satu keterampilan berbahasa yang kompleks. Kegiatan menulis, paling tidak melibatkan aspek penggunaan bahasa dan pengolahan isi.Bahkan jika dipandang sebagai bagian kemampuan komunikatif, kegiatan menulis melibatkan kompetensi gramatikal, kompetensi sosio linguistik, kompetensi discourse/ wacana, dan kompetensi strategik.

Berdasarkan hasil observasi awal di kelas VII-A terlihat bahwa keterampilan menulis sajak siswa masih rendah. Terdapat beberapa siswa masih mendapatkan nilai 55,00 dalam kegiatan menulis sajak padahal 
KKM yang harus dicapai siswa adalah 75,00. Selain itu, diperoleh gambaran kondisi siswa awal sebelum penelitian pada saat proses pembelajaran menulis sajak berlangsung. Terlihat siswa tidak terlalu antusias dalam pembelajaran sehingga kegiatan menulis sajak di kelas menjadi kurang menarik.Dari hasil pengamatan dapat diketahui terdapat banyak siswa yang masih kurang terampil dalam menulis sajak dengan memperhatikan unsur tema, diksi, larik, tipografi dan amanat. Berdasarkan informasi yang diperoleh, dengan adanya penggunaan metode ceramah membuat siswa cenderung hanya mendengarkan apa yang disampaikan oleh guru sehingga siswa tidak terlibat aktif dalam pembelajaran. Pembelajaran ceramah dengan kondisi siswa tersebut membuat motivasi belajar dalam menulis sajak rendah.

Dari latar belakang yang telah diuraikan, dapat didentifikasi beberapa masalah sebagai berikut 1) penggunaan metode ceramah dalam membuat sajak membuat siswa cenderung hanya mendengarkan apa yang disampaikan oleh guru sehingga siswa tidak terlibat aktif dalam pembelajaran. Hal tersebut membuat motivasi belajar siswa dalam menulis sajak rendah. 2) terdapat banyak siswa yang masih kurang terampil dalam menulis sajak dengan memperhatikan unsur tema, diksi, larik, tipografi dan amanat. 3) siswa kebingungan ketika menulis sajak sunda karena ide, imajinasi, dan kreativitas yang akan mereka tuliskan dalam sajak terbatas selain itu juga siswa kesulitan dalam memilih gaya bahasa (undak usuk basa) dan pemilihan kata dalam membuat sajak sunda. Adapun tujuan dari penelitian ini adalah untuk mengetahui sejauhmana peningkatan keterampilan dalam menulis sajak setelah menggunakan media gambar pada siswa kelas VII-A SMP Negeri 2 Jatinangor Kabupaten Sumedang

Manfaat secara umum diharapkan dari penelitian ini adalah bagi siswa yaitu memiliki keterampilan menulis sajak dengan baik, selain itu juga dapat meningkatkan kreativitas berfikir siswa sedangkan manfaat bagi guru adalah guru memiliki kemampuan memperbaiki proses pembelajaran melalui suatu kajian yang mendalam terhadap apa yang terjadi dikelasnya, dan bagi sekolah adalah dapat menjadi suatu bahan acuan terhadap putusan yang tepat dalam penggunaan media pembelajaran yang tepat pada mata pelajaran bahasa sunda khususnya dalam kegiatan belajar menulis sajak.

Dalam tinjauan pustaka disebutkan bahwa sajak dalam sastra sunda bukan karya sastra asli, melainkan pengaruh dari sastra Indonesia. Menurut Mustappa (2015:24), sebelum sajak sunda berkembang seperti sekarang ini dimasyarakat sunda. Dari sejarahnya, sajak sunda sendiri awalnya tidak diterima oleh masarakat Sunda. berbeda dengan carita pondok, yang dapat dengan mudah diterima oleh masyarakat sunda. Alasannya kala itu, karena sajak bukanlah karya sastra untuk orang sunda. Dalam membaca sajak, ada beberapa hal yang harus diperhatikan, yaitu intonasi atau lafal, dan cara penjiwaan dari penyampaian isi sajak. Unsur-unsur sajak diantaranya meliputi pikiran (sense), rasa (feeling), gaya (tone), dan maksud (intention).

Sajak merupakan sebuah karya sastra karangan tentang luapan perasaan hati seseorang, baik itu dari pengalaman, masalah, curahan hati, dan sebagainya, yang tidak selalu harus memperhatikan aturan atau patokan dalam pembuatannya, namun dalam pembuatan sajak, ada hal-hal yang perlu diperhatikan yaitu diksinya, atau pemilihan dalam membangun kata-katanya. Selain itu, terkadang sering mendengar dengan istilah sajak bebas, sajak bebas disini tentunya relatif. Artinya, sajak bisa ditulis secara bebas, tidak harus selalu memperhatikan 
jumlah suku dalam setiap baitnya, atau dalam setiap akhir penulisannya. Sebagai contoh misalnya, jika kita bandingkan sajak dengan sisindiran. Dalam hal ini, sajak tidak selalu harus memperhatikan cangkang dan isi yang merupakan aturan khusus yang harus ada dalam pembuatan sebuah sisindiran.

Keterampilan menulis sajak merupakan salah satu bentuk menulis kreatif, menulis sajak adalah suatu kegiatan intelektual, yakni kegiatan yang menuntut seseorang harus benar-benar cerdas, menguasai bahasa, luas wawasannya, dan peka perasaannya. Menulis sajak bermula dari proses kreatif, yakni mengimajikan atau mengembangkan fakta-fakta empirik yang kemudian diwujudkan dalam bentuk sajak. Kemudian, untuk menuangkannya menjadi sebentuk sajak, kita harus terlebih dahulu memahami unsur-unsur pembentuk sajak itu sendiri (Rusyana, 1982:26)

\section{Menurut Mustappa} keterampilan menulis sajak dapat dilihat melalui jalan tes; karena tes merupakan suatu cara dalam angka kegiatan evaluasi, yang di dalamnya terdapat berbagai item atau serangkaian tugas yang harus dikerjakan atau dijawab oleh siswa, kemudian pekerjaan dan jawaban itu akan menghasilkan nilai tentang perilaku siswa tersebut. adapun menurut pendapat (Ganie, 2013:305) mengungkapkan bahwa cara menilai kemampuan menulis sajak /puisi adalah melalui jalan tes. namun, ditegaskan olehnya bahwa penilaian yang dilakukan terhadap sajak/puisi siswa biasanya bersifat holistik, impresif, dan selintas; yaitu penilaian yang bersifat menyeluruh berdasarkan kesan yang diperoleh dari membaca sajak/puisi siswa secara selintas.

Selain penilaian yang bersifat holistik, diperlukan pula penilaian secara analitis agar guru dalam memberikan nilai secara lebih objektif dan dapat memperoleh informasi lebih rinci tentang kemampuan siswanya.
Penilaian dengan pendekatan analitis merinci tulisan dalam kategori tertentu. Pengkategorian itu sangatlah bervariasi, bergantung pada jenis tulisan itu sendiri. Namun pada pokoknya pengkategorian hendaknya meliputi: (1) kualitas dan ruang lingkup isi, (2) organisasi dan penyajian isi, (3) gaya dan bentuk bahasa, (4) mekanik: tata bahasa, ejaan, tanda baca, keterampilan tulisan, dan kebersihan, dan (5) respon afektif guru terhadap karya tulis

Adapun pengertian media gambar menurut Sudjana \& Rivai (2013:235) menyimpulkan media adalah alat yang menyampaikan atau menghantarkan pesanpesan pengajaran". Jadi media merupakan segala sesuatu yang dapat menyalurkan pesan, merangsang pikiran, perasaan dan kemauan siswa sehingga mendorong terjadinya proses belajar pada dirinya. Media pendidikan adalah seperangkat alat bantu atau pelengkap yang digunakan oleh guru atau pendidik dalam rangka berkomunikasi dengan siswa atau siswa. Alat bantu itu disebut media pendidikan sedangkan komunikasi adalah sistem penyampaiannya. Menurut Andayani (2015:30) mengemukakan teknik pembelajaran menulis dan gambar bertujuan agar siswa dapat menulis dengan cepat berdasarkan gambar yang dilihat. Gambar dan foto adalah media gambar yang sudah lazim dan umum dipakai dalam dunia pendidikan untuk mendukung proses belajar megajar. Gambar atau foto grafi dapat memberikan gambaran tentang segala sesuatu seperti, binatang, orang, tempat, atau peristiwa. Selanjutnya, Taringan (2008:209), menjelaskan teknik menulis sajak berdasarkan media gambar merupakan teknik yang sangat dianjurkan oleh para ahli. Gambar yang kelihatannya diam sebenarnya banyak berkata bagi mereka yang peka dan penuh imajinasi. Oleh karena itu, pemilihan gambar harus tepat, menarik, dan merangsang 
imajinasi siswa.

Berkaitan dengan media gambar Sadiman, Rahardjo, Haryono, \& Harjito (2018:29) mengatakan media gambar adalah media yang pada umumnya dipakai, yang dapat dimengerti dan dimiliki dimana-mana, ada pepatah cina yang mengatakan bahwa sebuah gambar berbicara lebih banyak daripada seribu kata. Pendapat yang lain dikemukakan oleh Munadi (2012:25) yang mengemukakan bahwa media gambar ialah alat visual yang penting, mudah didapat dan memberikan penggambaran visual yang konkret. Oirdjosastrosoemarto (1981) dalam Safei (2007) memberikan batasan bahwa media gambar adalah salah satu jenis bahasa yang memungkinkan terjadinya komunikasi, ia merupakan jenis bahasa yang diekspresikan lewat tanda dan simbol. mendefinisikan media gambar adalah media yang merupakan reproduksi bentuk asli dalam dua dimensi yang berupa foto dan lukisan.

Berdasarkan pendapat yang telah dikemukakan diatas, maka dapat disimpulkan bahwa pengertian media gambar adalah salah satu alat visual yang berasal dari reproduksi bentuk asli ke dalam dua dimensi baik itu berupa foto, maupun lukisan yang dapat memungkinkan terjadinya komunikasi dari pemberi pesan ke penerima pesan.

Media gambar merupakan media yang cocok untuk pembelajaran menulis sajak. Melalui media gambar, siswa akan terbantu dalam menuangkan ide atau gagasannya ke dalam bentuk tulisan dikarenakan gambar sifatnya konkrit dan lebih realistis. Hal ini sesuai dengan tahapan pemikiran operasional konkret yang membutuhkan media yang nyata.

Selain itu, telah banyak penelitian yang membahas mengenai tema ini dimana mereka lebih menekankan pada kemampuan menulis puisi dengan media gambar, beberapa penelitian yang telah dilakukan adalah penelitian Ekasari, Nuryatin, \& Suwitno (2014); Helentari, Heryana, \& Wartiningsih (2016); Isyani \& Ikhwanuddin (2016); Permana \& Indihadi (2018); Yuliyanto (2009). Berdasarkan uraian di atas, maka penulis berkesimpulan bahwa dengan memanfaatkan media gambar siswa akan mampu menyusun kata-kata yang akan dibuatnya menjadi sajak, siswa juga akan berimajianasi dengan baik melalui gambar yang ia lihat sehingga siswa akan dengan mudah menuangkannya ke dalam kata-kata dan kemudian menjadi sajak.

\section{METODE PENELITIAN}

Pendekatan penelitian yang digunakan adalah Penelitian Tindakan Kelas (PTK) atau Classroom Action Research (CAR) tipe penelitian tindakan partisipan atau kolaborasi. Dalam penelitian ini, peneliti selain aktif meneliti (mendiagnosis, merancang tindakan, melaksanakan tindakan, memantau, dan menganalisis. Peneliti juga ikut terlibat dalam kegiatan mulai dari awal hingga akhir. Konsep pokok penelitian tindakan kelas terdiri dari empat komponen, yaitu:: perencanaan (planning), tindakan (acting), pengamatan (observing), dan refleksi (reflecting). hubungan keempat komponen itu dipandang sebagai satu siklus.

Adapun sifat dari penelitian ini adalah bersifat kualitatif, karena pendekatan ini hanya mendeskripsikan data kemudian dianalisis tanpa diikuti pengujian hipotesis. Kegiatan penelitian tindakan kelas dilakukan dengan maksud untuk mencari inovasi baru dalam cara mengajar dengan harapan agar ketuntasan belajar dapat tercapai. Penelitian ini dilaksanakan di SMP Negeri 2 Jatinangor Kabupaten Sumedang. dilaksanakan pada awal Bulan maret sampai dengan bulan April 2017. dalam kegiatan penelitian ini yang menjadi subjek penelitian adalah siswa di kelas VII-A dengan jumlah siswa 38 orang, 
Metode pengumpulan data yang digunakan dalam penelitian ini yakni observasi (pengamatan), wawancara (angket) dan tes keterampilan menulis sajak serta dokumentasi kegiatan. Penelitian menggunakan beberapa instrumen untuk mengumpulkan data. Instrumen yang digunakan dalam penelitian ini adalah lembar observasi dan lembar penilaian menulis sajak. Lembar observasi aktifitas siswa dan guru selama proses pembelajaran menulis sajak, lembar observasi digunakan sebagai pedoman peneliti untuk melaksanakan observasi guna mendapatkan data yang diinginkan melalui pengamatan kegiatan guru dan siswa selama proses belajar mengajar berlangsung.

Hasil tes dalam penelitian ini digunakan untuk mengukur pencapaian keterampilan menulis sajak dengan menggunakan media gambar pada tabel 1 . Dalam penelitian ini, peneliti menuliskan beberapa karakteristik sajak yang sesuai untuk siswa kelas VII sehingga dapat menjadi dasar dalam penilaian hasil tes ini yaitu tema, diksi, banyaknya baris (larik), tipografi dan amanat.

Tabel 1. Kisi-Kisi Penilaian Keterampilan Menulis Sajak

\begin{tabular}{clc}
\hline No & Aspek yang di Nilai & Bobot \\
\hline 1 & Tema & 15 \\
\hline 2 & Diksi & 20 \\
\hline 3 & Banyaknya baris & 25 \\
\hline 4 & Tipografi & 20 \\
\hline 5 & Amanat & 20 \\
\hline & Total skor & 100 \\
\hline & &
\end{tabular}

Adapun lembar angket diberikan kepada seluruh siswa untuk mengetahui respon ketertarikan siswa terhadap kegiatan pembelajaran dengan metode penggunaan media gambar dalam menulis sajak. Analisis data merupakan kegiatan setelah datadata terkumpul. analisis data adalah proses mencari dan menyusun secara sistematis data yang diperoleh dari hasil wawancara, catatan lapangan, dan bahan-bahan lain, sehingga dapat mudah dipahami, dan temuannnya dapat diinformasikan kepada orang lain. Dalam penelitian ini, analisis data yang digunakan adalah deskriptif kualitatitif. data kualitatif diperoleh dari lembar observasi aktivitas siswa selama proses pembelajaran menulis sajak.

Indikator keberhasilan dalam penelitian ini adalah meningkatnya keterampilan menulis sajak menggunakan media gambar yang dilihat selama proses pembelajaran berlangsung. Penelitian dikatakan berhasil dan akan dihentikan apabila 1) nilai rata-rata kelas berdasarkan nilai tes mnenulis sajak meningkat dari pra tindakan ke siklus I dan ke siklus II. 2) proses pelaksanaan pembelajaran dikatakan berhasil jika ada peningkatan jumlah siswa yang aktif setiap siklusnya, siklus dihentikan jika dalam proses pelaksanaan pembelajaran sudah mencapai kreteria baik $75 \%$ dari seluruh siswa. 3) pemahaman dalam keterampilan menulis sajak dikatakan berhasil jika ada peningkatan siswa yang tuntas setiap siklusnya, siklus dihentikan jika dalam pemahaman siswa yang tuntas sudah mencapai $75 \%$ dari seluruh siswa dan 4) ratarata siswa satu kelas telah memenuhi standar keberhasilan yaitu 70,00.

\section{HASIL DAN PEMBAHASAN}

\subsection{Hasil}

Pada bagian ini disajikan hasil penelitian tindakan kelas yang berupa hasil tes pada kondisi awal merupakan keterampilan menulis sajak sebelum menggunakan media gambar. Sedangkan, hasil tes pada siklus I dan II merupakan perbaikan keterampilan menulis sajak setelah dilakukan pembelajaran dengan menggunakan media gambar. Hasil tes diuraikan dalam bentuk data kuantitatif. Untuk hasil nontes berupa hasil observasi 
akan diuraikan dalam bentuk deskripsi data kualitatif.

\section{A. Kondisi Awal}

Pembelajaran pada kondisi awal menunjukkan siswa terlihat kurang antusias sehingga pembelajaran menulis sajak menjadi tidak menarik. Pembelajaran menggunakan metode ceramah membuat siswa cenderung hanya mendengarkan apa yang disampaikan oleh guru sehingga siswa tidak terlibat aktif dalam pembelajaran menulis sajak. Selain itu, masih adanya siswa yang terlihat mondar mandir selama proses pembelajaran berlangsung. Berdasarkan hasil pengamatan pada kondisi awal, pembelajaran sajak belum menggunakan media yangbervariasi secara optimal sehingga siswa kurang termotivasi dan tertarik dalam proses pembelajaran. Tes padakondisiawal merupakan tesketerampilan menulis sajak sebelum dilakukan tindakan penelitian. Tes keterampilan menulis sajak ini bertujuan untuk mengetahui kondisi awal keterampilan menulis sajak pada siswa kelas VII-A di SMP Negeri 2 Jatinangor Kabupaten Sumedang.dengan hasil yang dapat dilihat pada tabel dibawah ini.

Tabel 2. Distribusi Frekuensi Keterampilan Menulis Sajak Pada Kondisi Awal

\begin{tabular}{|c|c|c|c|c|c|}
\hline No & Rentang nilai & $\mathbf{F}$ & Bobot skor & $\%$ & Kategori \\
\hline 1 & $86-100$ & 2 & 180 & $5 \%$ & Sangat baik \\
\hline 2 & $71-85$ & 8 & 640 & $21 \%$ & Baik \\
\hline 3 & 56-70 & 13 & 871 & $34 \%$ & Cukup \\
\hline 4 & $41-55$ & 12 & 284 & $32 \%$ & Kurang \\
\hline 5 & $\leq 40$ & 3 & 120 & $7 \%$ & Sangat kurang \\
\hline & $\sum$ & 38 & 2095 & $100 \%$ & \\
\hline \multicolumn{2}{|c|}{$\frac{2}{\text { Rata-rata }}$} & \multicolumn{4}{|c|}{$X=2095 / 38=55,13$} \\
\hline
\end{tabular}

Berdasarkan hasil seperti yang terlihat pada tabel 2 menunjukkan bahwa rata-rata keterampilan menulis sajak pada siswa kelas VII-A masih termasuk ke dalam kategori rendah yaitu 55,13. Dari seluruh siswa yang berjumlah 38 orang hanya terdapat 2 siswa ke dalam kategori sangat baik, 3 orang siswa atau sebesar $21 \%$ termasuk ke dalam kategori baik, 13 siswa atau sebesar 34\% termasuk ke dalam kategori cukup sedangkan masih terdapat 15 siswa atau sebesar $39 \%$ masuk kedalam kategori kurang dan sangat kurang.

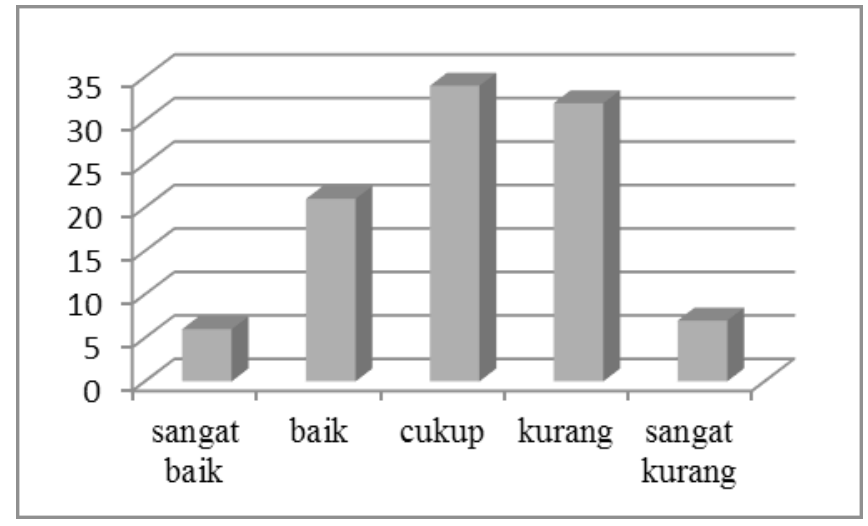

Grafik 1. Presentase Keterampilan Menulis Sajak Pada Kondisi Awal

Dari grafik 1 diatas menunjukan bahwa sebagian besar siswa dalam pembelajaran menulis sajak masih termasuk ke dalam kategori kurang. maka diperlukan suatu perbaikan untuk meningkatkan nilai siswa. Tindakan yang dilakukan salah 
satunya adalah penggunaan media gambar dalam pembelajaran menulis sajak.

\section{B. Pelaksanaan Siklus I}

Siklus I merupakan pemberlakuan tindakanawalpenelitiandenganmenggunakan media gambar. Berdasarkan pengamatan yang dilakukan pada pembelajaran menulis sajak pada siklus I ini terlihat bahwa media gambar yang digunakansangat bermanfaat bagi siswa. Pada siklus ini I ini telah dilaksanakan tindakan berupa penjelasan unsur-unsur sajak.

Tabel 3. Pengamatan Terhadap Kegiatan Belajarsiswa Pada Siklus 1

\begin{tabular}{clcc}
\hline No & \multicolumn{1}{c}{ Unsur yang di nilai } & $\mathbf{\%}$ & Kategori \\
\hline 1 & $\begin{array}{l}\text { Siswa sungguh-sungguh dalam pembelajaran menulis sajak dengan adanya } \\
\text { media gambar }\end{array}$ & 72.56 & Baik \\
\hline 2 & Siswa bersemangat dalam mengungkapkan gagasannya dengan adanya gambar & 73.26 & Baik \\
\hline 3 & $\begin{array}{l}\text { Siswa mempunyai antusiasme/ minat tinggi dalam menulis sajak dengan adanya } \\
\text { gambar }\end{array}$ & 72.57 & Baik \\
\hline 4 & Siswa aktif berpartispasi dalam diskusi kelompok dengan adanya gambar & 67.70 & Baik \\
\hline 5 & $\begin{array}{l}\text { Siswa merasa termotivasi dan tertarik dalam pembelajaran menulis sajak } \\
\text { dengan adanya media gambar }\end{array}$ & 73.61 & Baik \\
\hline 6 & Siswa saling berkompetisi menulis sajak dengan adanya media gambar & 67.01 & Baik \\
\hline & Rata-rata & 71.12 & Baik \\
\hline
\end{tabular}

Berdasarkan tabel 3 hasil rekapitulasi pengamatan selama 2 kali pertemuan diatas maka diperoleh hasil bahwa jumlah persentase dari keseluruhan total aspek yang diamati menunjukkan $71.12 \%$ dengan kategori baik pada siklus I. Adapun keseluruhan hasil tes pelaksanaan menulis sajak pada siklus I dapat dilihat dari tabel berikut.

Tabel 4. Rekapitulasi Data Keterampilan Menulis Sajak Siswa Pada Siklus I

\begin{tabular}{clcccl}
\hline No & Rentang nilai & $\mathbf{F}$ & Bobot skor & $\mathbf{\%}$ & Kategori \\
\hline 1 & $86-100$ & 2 & 164 & $5 \%$ & Sangat baik \\
\hline 2 & $71-85$ & 12 & 903 & $32 \%$ & Baik \\
\hline 3 & $56-70$ & 19 & 1224 & $49 \%$ & Cukup \\
\hline 4 & $41-55$ & 5 & 270 & $13 \%$ & Kurang \\
\hline 5 & $\leq 40$ & - & - & - & Sangat kurang \\
\hline$\sum$ & \multicolumn{5}{l}{$\mathrm{X}=2546 / 38=67,01$} \\
\hline Rata-rata
\end{tabular}

Tabel 4 menunjukkan bahwa hasil tes keterampilan menulis sajak pada siklus I. nilai ratarata yang diperoleh mencapai 67,01 dengan kategori cukup. Rata-rata ini menunjukkan terjadinya peningkatan keterampilan dalam menulis sajak dengan menggunakan media gambar dibandingkan dengan nilai rata-rata pada kondisi awal.

Dalam refleksi pada siklus I pembelajaran menulis sajak belum sepenuhnya berjalan dengan baik dan optimal. Hasil tes tindakan pada siklus I sudah mengalami peningkatan akan tetapi belum mencapai standar yang diharapkan. Nilai rata-rata tes keterampilan menulis sajak pada pada siklus
I menunjukkan angka 67.01. Hasil ini lebih baik bila dibandingkan dengan kondisi awal yang hanya mencapai nilai rata-rata 55,13 . walaupun mengalami peningkatan sebesar 11,88 tetapi nilai rata-rata ini belum mencapai standar 70.00 .

Dari hasil refleksi, terlihat keterampilan siswa dalam menulis sajak dengan menggunakan media gambar mulai berkembang dengan baik meskipun belum mencapai hasil yang diharapkan yaitu masih belum maksimalnya peningkatan unsur diksidan amanat, sedangkan dari hasil refleksi bersama pengamat terungkap juga bahwa masih ada beberapa aspek dan kriteria 
yang perlu ditingkatkan dalam memaksimalkan keterampilan siswa untuk menulis sajak dengan menggunakan media gambar, yakni a) gambar harus lebih jelas dan menarik untuk merangsang kreativitas siswa b) unsur sajak yang harus ditingkatkan siswa adalah diksi dan amanat c) guru perlu memberikan bimbingan secara terus menerus sehingga siswa bisa paham dan mengerti dalam menulis sajak dan d) motivasi siswa harus ditingkatkan sehingga siswa mempunyai minat yang tinggi dalam menulis sajak

Oleh karena itu, berdasarkan hasil refleksi datas, maka kegiatan pembelajaran menulis sajak dengan menggunakan media gambar pada siswa kelas VII-A SMP Negeri 2 Jatinangor perlu dilanjutkan pada siklus selanjutnya dengan merancang pembelajaran menulis sajak yang lebih optimal dan lebih baik dari pembelajaran yang dilakukan pada siklus I.

\section{Pelaksanaan siklus II}

Pada pembelajaran siklus II ini, guru dan pengamat merevisi kekurangan-kekurangan yang terjadi pada siklus I. Pada siklus II langkah-langkah pembelajaran yang dilakukan sama halnya dengan siklus I. Untuk yang membedakannya dengan siklus I adalah guru menyiapkan gambar dengan tema yang berbeda dan menarik sehingga gambar dapat lebih efektif dalam membantu siswa menulis sajak

Berdasarkan pengamatan pada tabel 5 yang dilakukan pada pembelajaran menulis sajak pada siklus II ini terlihat bahwa media gambar yang digunakan sangat bermanfaat bagi siswa. Pada siklus II ini telah dilaksanakan tindakan berupa penjelasan unsur-unsur sajak. Berdasarkan tabel hasil rekapitulasi pengamatan selama dua kali pertemuan dapat diperoleh bahwa jumlah persentase dari keseluruhan total aspek yang diamati menunjukkan $82.58 \%$ dengan kategori sangat baik pada siklus II. Adapun penjelasannnya adalah sebagai berikut

Tabel 5. Pengamatan Terhadap Kegiatan Belajar Siswa Pada Siklus II

\begin{tabular}{|c|c|c|c|}
\hline No & Unsur yang di nilai & $\%$ & Kategori \\
\hline 1 & $\begin{array}{l}\text { Siswa sungguh-sungguh dalam pembelajaran menulis sajak dengan adanya } \\
\text { media gambar }\end{array}$ & 81.94 & sangat baik \\
\hline 2 & Siswa bersemangat dalam mengungkapkan gagasannya dengan adanya gambar & 84.37 & sangat baik \\
\hline 3 & $\begin{array}{l}\text { Siswa mempunyai antusiasme/ minat tinggi dalam menulis sajak dengan adanya } \\
\text { gambar }\end{array}$ & 83.33 & sangat baik \\
\hline 4 & Siswa aktif berpartispasi dalam diskusi kelompok dengan adanya gambar & 80.90 & sangat baik \\
\hline 5 & $\begin{array}{l}\text { Siswa merasa termotivasi dan tertarik dalam pembelajaran menulis sajak dengan } \\
\text { adanya media gambar }\end{array}$ & 82.98 & sangat baik \\
\hline \multirow[t]{2}{*}{6} & Siswa saling berkompetisi menulis sajak dengan adanya media gambar & 81.94 & sangat baik \\
\hline & Rata-rata & 82.58 & sangat baik \\
\hline
\end{tabular}

Sementara itu hasil tes pelaksanaan

tabel di bawah ini.

menulis sajak pada siklus II dapat dilihat dari

Tabel 6. Rekapitulasi Data Keterampilan Menulis Sajak Siswa Pada Siklus II

\begin{tabular}{cccccc}
\hline No & Rentang nilai & F & Bobot skor & $\mathbf{\%}$ & Kategori \\
\hline 1 & $86-100$ & 4 & 355 & 10 & Sangat baik \\
\hline 2 & $71-85$ & 9 & 756 & 23 & Baik \\
\hline 3 & $56-70$ & 24 & 1673 & 63 & Cukup \\
\hline 4 & $41-55$ & 1 & 55 & 2 & Kurang \\
\hline 5 & $\leq 40$ & - & & - & Sangat kurang \\
\hline \multicolumn{7}{l}{ Rata-rata } & 38 & 3112 & 100 & Sangat baik \\
\hline
\end{tabular}


Tabel 6 menunjukkan hasil tes keterampilan menulis sajak siklus II. Pada pertemuan I nilai rata-rata mencapai 81,94 dengan kategori sangat baik. Berdasarkan hasil perolehan data di atas maka dapat disimpulkan bahwa penggunaan media gambar dimaksudkan agar siswa terangsang kreativitasnya dalam menulis sajak. Media gambar menjadi faktor utama dalam proses pembelajaran. Sehingga sebelum proses pembelajaran guru sudah menyiapkan gambar yang akan ditampilkan dalam ukuran besar. Melalui cara seperti ini diharapkan siswa mampu berpikir dengan logis sehingga pembelajaran menjadi bermakna. Penggunaan media gambar dalam menulis sajak ini akan sangat menarik siswa.

Atas dasar uraian di atas, terlihat adanya peningkatan aktivitas siswa selama proses pembelajaran menulis sajak berlangsung. Peningkatan terlihat dari siklus I ke siklus II dengan persentase peningkatan tertinggi yaitu aspek siswa saling berkompetisi menulis sajak dengan adanya gambar. Sedangkan persentase peningkatan terendah yaitu aspek siswa merasa termotivasi dan tertarik dalam pembelajaran menulis sajak dengan adanya gambar. Maka dari itu, diperlukan penelitian lebih lanjut yang dilakukan guru sehingga rata-rata nilai keterampilan menulis sajak dapat mencapai kategori sangat baikBerdasarkan hasil temuan penelitian pada siklus I dan siklus II di atas jelaslah bahwa penggunaan media gambar, mampu meningkatkan keterampilan siswa dalam menulis sajak.

Dari hasil penelitian dalam mengamati perkembangan aktivitas siswa selama proses pembelajaran berlangsung. diperoleh halhal sebagai berikut: siswa sangat tertarik dengan menggunakan media gambar dalam menulis sajak, kemudian keterampilan siswa dalam menulis sajak meningkat terlihat dari produk sajak yang dihasilkan, sebagian besar siswa telah dapat menulis sajak dengan memperhatikan unsur tema, diksi, larik, tipografi dan amanat walaupun masih ada yang siswa yang belum memperhatikan unsur-unsur tersebut.

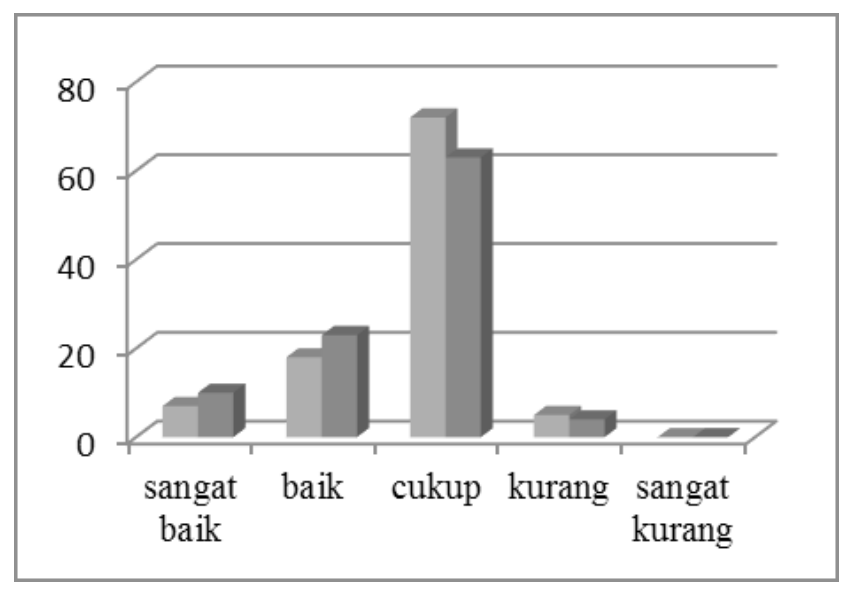

Grafik 2. Peningkatan Prosentase Keterampilan Menulis Sajak pada Siklus I dan II

Dari grafik 2 diketahui terjadi peningkatan hasil belajar siswa dalam membuat sajak sunda, membutuhkan waktu yang sedikitlamabagi siswa namun demikian terlihat juga bahwa peningkatan keterampilan menulis melalui penggunaan media gambar telah memenuhi standar keberhasilan di atas nilai KKM 70,00 yaitu dengan perolehan skor rata-rata nilai siswa menjadi 81,94. Oleh karena itu, telah terjadi peningkatan dan memenuhi standar keberhasilan maka penelitian dicukupkan sampai pada siklus II. 


\subsection{Pembahasan}

Untuk mengatasi permasalahan belajar dalam menulis sajak sunda maka peneliti memilih kegiatan dalam menulis sajak dengan menggunakan media gambar sebagai bahan kajian dalam kegiatan pembelajaran karena denganmenggunakanmediagambarsiswa diajak dengan mengoptimalkan penglihatan terhadap gambar yang dilihatnya dan mengeksplorasi imajinasinya, kemudian dituangkan oleh siswa melalui kata-kata yang mengandung bahasa sajak, Hal ini sangat sesuai untuk pembelajaran menulis sajak karena dengan melihat gambar memudahkan siswa untuk menuangkan katakata dalam bahasa sajak dengan meliaht gambar secara nyata dan detail. Dengan kata lain, media gambar ini akan memudahkan siswa untuk menangkap ide-ide ke dalam tulisannya.

Menurut Nurjamal, Sumirat, \& Darwis (2011:69) mengemukakan bahwa melalui kegiatan menulis, penulis bisa mengungkapkan gagasan, pikiran, perasaan, pendapat, kehendak, dan pengalamnannya kepada pihak lain. Hasil dari kegiatan menulis ini dapat berupa sajak. Sementara itu Nurgiyantoro (2005:313), menjelaskan sajak harus mampu mengungkapkan secara lebih banyak daripada sekedar apa yang tertulis dan sekaligus ditulis dan diekspresikan lewat bahasa yang khas sajak yang lain daripada bahasa keseharian.

Berdasarkan hasil tes pada siklus I menunjukkan hasil tes keterampilan menulis sajak.
Pada pertemuan I nilai rata-rata mencapai 67,01 dengan kategori cukup. Rata-rata ini menunjukkan terjadinya peningkatan keterampilan menulis sajak dengan menggunakan media gambar dibandingkan dengan rata-rata pada kondisi awal, walaupun peningkatannya belum maksimal. sehingga peneliti melanjutkannya pada siklus yang ke II dengan memperbaiki kekurangan-kekurangan yang ada pada siklus I. Dalam pelaksanaan tindakan siklus II yang membedakan adalah gambar yang digunakan lebih jelas dan menarik daripada di siklus I. Dari hasil siklus II diperoleh rata-rata siswa sebesar 81,94 dengan kategori baik. Hal yang menyebabkan ratarata tes belum mencapai kategori sangat baik karena masih adanya siswa yang belum memperhatikan pembelajaran menulis sajak. Dari hasil tes menunjukkan keterampilan menulis sajak siklus II.

Pada pertemuan I nilai rata-rata mencapai 69.16 dengan kategori cukup. dari 38 siswa, tidak terdapat siswa ke dalam kategori sangat kurang, 3 siswa atau sebesar 7\% termasuk ke dalam kategori sangat baik, 7 siswa atau sebesar $18 \%$ termasuk ke dalam kategori baik dan 26 orang atau $73 \%$ termasuk kategori cukup dan masih terdapat 2 orang siswa yang masuk kategori kurang, Walaupun pada pertemuan ke dua siklus 2, terjadi sedikit peningkatan, yaitu 4 orang siswa masuk kedalam kategori sangat baik, 9 orang siswa atau sekitar 23\% termasuk kategori baik, 24 orang siswa atau 63 $\%$ kategori cukup dan hanya 1 orang saja yang masih memiliki kategori kurang.

Tabel 7. Data Peningkatan Aktivitas Menulis Sajak Menggunakan Media Gambar

\begin{tabular}{clccc}
\hline No & \multicolumn{1}{c}{ Aspek yang di nilai } & $\begin{array}{c}\text { Siklus 1 } \\
\mathbf{\%}\end{array}$ & $\begin{array}{c}\text { Siklus II } \\
\mathbf{\%}\end{array}$ & $\begin{array}{c}\text { Peningkatan } \\
\mathbf{\%}\end{array}$ \\
\hline 1 & $\begin{array}{l}\text { Siswa sungguh-sungguh dalam pembelajaran menulis sajak } \\
\text { dengan adanya gambar }\end{array}$ & 72.56 & 81.94 & 9.38 \\
\hline 2 & $\begin{array}{l}\text { Siswa bersemangat dalam mengungkapkan gagasannya dengan } \\
\text { adanya gambar }\end{array}$ & 73.26 & 84.37 & 11.11 \\
\hline 3 & $\begin{array}{l}\text { Siswa mempunyai antusiasme/ minat tinggi dalam menulis sajak } \\
\text { dengan adanya gambar Siswa mempunyai antusiasme/ minat } \\
\text { tinggi dalam menulis sajak dengan adanya gambar }\end{array}$ & 72.57 & 83.33 & 10.76 \\
\hline 4 & $\begin{array}{l}\text { Siswa aktif berpartispasi dalam diskusi dengan adanya gambar } \\
5\end{array}$ & $\begin{array}{l}\text { Siswa merasa termotivasi dan tertarik dalam pembelajaran } \\
\text { menulis sajak dengan adanya gambar }\end{array}$ & 73.61 & 82.98 \\
\hline 6 & Siswa saling berkompetisi menulis sajak dengan adanya gambar & 67.01 & 81.94 & 13.2 \\
\hline
\end{tabular}


Berdasarkan tabel 7 , terlihat adanya peningkatan aktivitas siswa selama proses pembelajaran menulis sajak berlangsung. Peningkatan terlihat dari siklus I ke siklus II dengan persentase peningkatan tertinggi yaitu aspek siswa saling berkompetisi menulis sajak dengan adanya gambar. Sedangkan persentase peningkatan terendah yaitu aspek siswa merasa termotivasi dan tertarik dalam pembelajaran menulis sajak dengan adanya gambar. Maka dari itu, diperlukan penelitian lebih lanjut yang dilakukan guru sehingga rata-rata nilai keterampilan menulis sajak dapat mencapai kategori sangat baik Berdasarkan hasil temuan penelitian pada siklus I dan siklus II di atas jelaslah bahwa penggunaan media gambar, mampu meningkatkan keterampilan siswa dalam menulis sajak.

Penggunaan media gambar dimaksudkan agar siswa terangsang kreativitasnya dalam menulis sajak. Media gambar menjadi faktor utama dalam proses pembelajaran. Sehingga sebelum proses pembelajaran guru sudah menyiapkan gambar yang akan ditampilkan dalam ukuran besar. Melalui cara seperti ini diharapkan siswa mampu berpikir dengan logis sehingga pembelajaran menjadi bermakna. Penggunaan media gambar dalam menulis sajak ini akan sangat menarik siswa

Dari pembahasan di atas maka penulis berpendapat bahwa keterampilan menulis sajak ini tidak dapat datang tiba-tiba, tetapi dapat dicapai melalui proses belajar dan berlatih secara terus menerus. Keterampilan menulis merupakan salah satu aspek keterampilan berbahasa yang bersifat produktif dan ekspresif sehingga dapat dicapai dengan banyak latihan dan bimbingan yang intensif karena sifatnya yang bukan teoritis. Oleh karena itu, peranan guru sangat menentukan. Guru harus memiliki keterampilan menulis sajak yang baik, di samping juga harus mampu mengajarkannya. Guru harus mampu merencanakan proses pembelajaran yang efektif. Metode dan media pembelajaran serta strategi belajar mengajar yang dipilih sangatlah berpengaruh terhadap hasil belajar siswa.

\section{KESIMPULAN}

Berdasarkan hasil analisis data dan pembahasan, dapat disimpulkan bahwa Proses pembelajaran menulis sajak yang dilakukan terhadap siswa kelas VII-A SMP Negeri 2 Jatinangor Kabupaten Sumedang dengan menggunakan media gambar ternyata kegiatan pembelajaran menjadi lebih menarik perhatian siswa, siswa dapat lebih banyak menemukan inspirasi dan ide dalam menulis sajak. Gambar atau foto yang ditempelkan di papan tulis oleh guru dapat memberikan gambaran tentang segala sesuatu seperti suasana atau peristiwa tertentu yang dapat membawa imajinasi siswa ke tempat tersebut. Gambar yang kelihatannya diam sebenarnya banyak berkata bagi mereka yang peka dan penuh imajinasi. Oleh karena itu, pemilihan gambar harus tepat, menarik, dan merangsang siswa. yang pada akhirnya dapat meningkatkan kegiatan pembelajaran, peningkatan tersebut dapat dilihat dari kesungguhan siswa dalam pembelajaran menulis sajak, semangat dalam mengungkapkan gagasannya, antusiasme/ minat tinggi dalam menulis sajak, aktif berpartispasi dalam diskusi, rasa termotivasi, tertarik dan saling berkompetisi menulis sajak.

Peningkatan hasil belajar siswa dalam menulis sajak sunda berdasarkan pada pengamatannya terhadap media gambar dapat diketahui dari hasil tes siswa pada siklus I nilai rata-rata mencapai 67,01 dengan kategori cukup. Rata-rata ini menunjukkan terjadinya peningkatan keterampilan menulis sajak dengan menggunakan media gambar dibandingkan dengan rata-rata pada kondisi awal, Dari hasil siklus II diperoleh nilai ratarata siswa sebesar 81,94 dengan kategori baik. 


\section{DAFTAR RUJUKAN}

Andayani. (2015). Problema dan Aksioma: Dalam Metodologi Pembelajaran Bahasa Indonesia. Yogyakarta: Deepublish.

Ekasari, A. D., Nuryatin, A., \& Suwitno, W. (2014). Peningkatan Keterampilan Menulis Puisi Melalui Strategi Pikir Plus dengan Menggunakan Media Gambar Peristiwa. Jurnal Pendidikan Bahasa Dan Sastra Indonesia, 3(1).

Ganie, T. N. (2013). Teori menulis puisi. Banjarmasin: Pustaka Banua.

Helentari, K., Heryana, N., \& Wartiningsih, A. (2016). Peningkatan Keterampilan Menulis Puisi Menggunakan Media Gambar dengan Teknik Kata Kunci Kelas VII I. Jurnal Pendidikan Dan Pembelajaran Untan, $5(11)$.

Isyani, I., \& Ikhwanuddin, I. (2016). Peningkatan Keterampilan Menulis Puisi Menggunakan Media Gambar Slide Pada Siswa Kelas 3 Sd Banyuripan Kecamatan Kasihan Kabupaten Bantul Yogyakarta. Didaktika, 5(1).

Munadi, Y. (2012). Media Pembelajaran; Sebuah Pendekatan Baru. Jakarta: Gaung Persada.

Mustappa, A. (2015). Wirahma sajak: panganteur apresiasi sajak Sunda : pikeun murid sakola lanjutan. Bandung: Pustaka Jaya.

Nurgiyantoro, B. (2005). Sastra Anak, Pengantar Pemahaman Dunia Anak. Yogyakarta: Gadjah Mada University Press.

Nurjamal, D., Sumirat, W., \& Darwis, R. (2011). Terampil Berbahasa. Bandung: Alfabeta.

Permana, D., \& Indihadi, D. (2018). Penggunaan Media Gambar terhadap Pembelajaran Menulis Puisi Peserta Didik. PEDADIDAKTIKA: Jurnal Ilmiah Pendidikan Guru Sekolah Dasar, 5(1), 193-205.

Rusyana, Y. (1982). Metode Pengajaran Sastra Sunda. Bandung: Gunung Larang.

Sadiman, A. S., Rahardjo, Haryono, A., \& Harjito. (2018). Media Pendidikan (Cetakan ke-14). Jakarta: PT. Raja Grafindo Persada.

Safei. (2007). Penggunaan Media Grafis dalam Proses Pembelajaran. Lentera Pendidikan, 1(1), 116-123.

Sudjana, N., \& Rivai, A. (2013). Media Pengajaran (Cetakan ke-11). Bandung: Sinar Baru Algesindo.

Taringan, H. G. (2008). Menulis Sebagai Suatu Keterampilan Berbahasa. Bandung: Angkasa.

Yuliyanto. (2009). Peningkatan Kemampuan Menulis Puisi dengan Media Gambar Karikatur melalui Teknik Pancingan Kata Kunci Siswa Kelas VIII F SMP Negeri 13 Semarang Tahun Pelajaran 2008/2009. Universitas Negeri Semarang. 